\title{
Transformation of a Rural Economy in the Zhujiang Delta
}

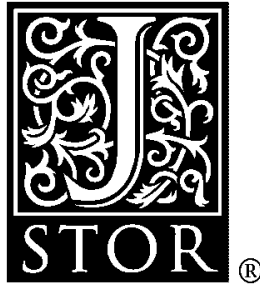

George C. S. Lin

The China Quarterly, No. 149. (Mar., 1997), pp. 56-80.

Stable URL:

http://links.jstor.org/sici?sici=0305-7410\%28199703\%290\%3A149\%3C56\%3ATOAREI\%3E2.0.CO\%3B2-Z

The China Quarterly is currently published by School of Oriental and African Studies.

Your use of the JSTOR archive indicates your acceptance of JSTOR's Terms and Conditions of Use, available at

http://www.jstor.org/about/terms.html. JSTOR's Terms and Conditions of Use provides, in part, that unless you have obtained prior permission, you may not download an entire issue of a journal or multiple copies of articles, and you may use content in the JSTOR archive only for your personal, non-commercial use.

Please contact the publisher regarding any further use of this work. Publisher contact information may be obtained at http://www.jstor.org/journals/soas.html.

Each copy of any part of a JSTOR transmission must contain the same copyright notice that appears on the screen or printed page of such transmission.

JSTOR is an independent not-for-profit organization dedicated to and preserving a digital archive of scholarly journals. For more information regarding JSTOR, please contact support@jstor.org. 


\title{
Transformation of a Rural Economy in the Zhujiang Delta*
}

\author{
George C. S. Lin
}

Dramatic social and economic change taking place in the Zhujiang Delta region has been a subject of extensive documentation. Much has been written on the growth and restructuring of the delta's regional economy, ${ }^{1}$ on its intensified social and economic linkages with Hong Kong and the outside world, ${ }^{2}$ and on its changing geographic patterns of urbanization and regional development. ${ }^{3}$ While the emergence of the Zhujiang Delta as one of the most dynamic economic regions has received wide recognition from scholars and the general public, the operating mechanism of economic and spatial transformation at the local level remains poorly understood. How has a rural economy under socialism been transformed after the intrusion of free market forces? What role is played by the state, the collective economy and the private sector in this process of transformation? Is the transformation process facilitated by the growth of market farming or rural industrial development? How has change in the political economy affected migration, land use and the natural environment? These questions are all open to further investigation.

* This research was funded at different stages by the Social Sciences and Humanities Research Council of Canada (Grant No. 752-92-0925), the International Development Research Center of Canada (Grant No. 91-1025-11), the Chiang Ching Kuo Foundation and the Hui Oi Chow Urbanization Trust Fund. I wish to thank Graham Johnson, Terry McGee, Alan Smart, Peter Foggin and Victor Sit for their comments and suggestions which helped improve an earlier version of this paper.

1. See Graham Johnson, "The political economy of Chinese urbanization: Guangdong and the Pearl River Delta region," in Gregory Guldin (ed.), Urbanizing China (Westport: Greenwood Press, 1992), pp. 185-220; C. P. Lo, "Recent spatial restructuring in Zhujiang Delta, South China: a study of socialist regional development strategy," Annals of the Association of American Geographers, Vol. 79, No. 2 (1989), pp. 293-308; Xu Xueqiang and Li Si-ming, "China's open door policy and urbanization in the Pearl River Delta region," International Journal of Urban and Regional Research, Vol. 14, No. 1 (1990), pp. 49-69; Zheng Tianxiang et al., Zhujiang sanjiaozhou jingji dili wangluo (Economic and Geographic Network of the Zhujiang Delta) (Guangzhou: Zhongshan University Press, 1991).

2. See Ezra Vogel, One Step Ahead in China: Guangdong Under Reform (Cambridge, MA: Harvard University Press, 1989); Reginald Kwok and Alvin So, The Hong Kong-Guangdong Link: Partnership in Flux (Armonk, NY: M.E. Sharpe, 1995); Gregory Guldin, "Towards a Greater Guangzhou: Hong Kong's sociocultural impact on the Pearl River Delta and beyond," paper presented at the Workshop on Hong Kong-Guangdong Integration, University of British Columbia, Vancouver, 1992); Alan Smart, "The emergence of local capitalisms in China: overseas Chinese investment and patterns of development," in Si-Ming Li, Wing-Shing Tang and Lan-Hung Nora Chiang (eds.), China's Regional Development: A Study of Spatial Transformation (forthcoming); Chi-Kin Leung, "Personal contacts, subcontracting linkages, and development in the Hong Kong-Zhujiang Delta region," Annals of the Association of American Geographers, Vol. 83, No. 2 (1993), pp. 272-302.

3. George Lin, Red Capitalism in South China (Vancouver: UBC Press, 1997); Xu Xueqiang et al. (eds.), Zhujiang sanjiaozhou de jingji fazhan yu chengshihua (Development and Urbanization of the Zhujiang Delta) (Guangzhou: Zhongshan University Press, 1988); Victor Sit (ed.), Resource and Development of the Pearl River Delta (Hong Kong: Wide Angle Press, 1984); Anthony Yeh et al., "Spatial development of the Pearl River Delta: development issues and research agenda," Asian Geographer, Vol. 8, No. 1/2 (1989), pp. 1-9.

(C) The China Quarterly, 1997 
Nanhai, a new municipality grown out of a rural county, is a case illustrative of the processes and consequences of economic and spatial transformation that has been taking place in the Zhujiang Delta since the reforms. Compared with other parts of the country, Nanhai is distinctive in at least three aspects. First, it is one of the most rapidly changing county-level economies with an extraordinary record of post-reform growth and development. Table 1 shows some major economic indicators that reveal the edge Nanhai has had over the national, provincial and regional averages. Between 1980 and 1990, Nanhai dramatically raised per capita national income from 667 yuan to 3,754 yuan and per capita net income for peasants from a mere 350 yuan to 1,705 yuan, moving up to a position well ahead of most county-level economies in the Zhujiang Delta and elsewhere. A comprehensive evaluation of economic performance of all counties in China, conducted by the state statistical authorities in 1991, ranked Nanhai number one in Guangdong province and number four in the nation, next only to the counties of Wuxi, Wujin and Jiangyin. $^{4}$

Secondly, rural industrialization in Nanhai has demonstrated a pattern quite different from those in other parts of the country. Township and village enterprises, for instance, have played an outstanding role in local economic development (Table 2). Their growth has been less dependent on state support, more reliant on market forces and better facilitated by various spontaneous local initiatives. ${ }^{5}$ More importantly, rural industrialization here has been achieved by a simultaneous mobilization of all local resources, particularly those from the five levels of county, township, district, village and individual. The Nanhai Model, known as "driving forward on five wheels" (wuge lunzi yiqi zhuan), has been recognized by economic planners and scholars in China as one of the three national models of rural industrialization, standing parallel to, but distinct from, the Sunan Model which emphasizes the collective sector and the Wenzhou Model whose mainstay is the private sector. ${ }^{6}$

Finally, Nanhai is distinguished by its relatively successful management of agricultural production at a sizeable scale (nongye shidu guimo jingying). As will be revealed in this study, the experience of Nanhai in developing large-scale market farming and mechanizing the cultivation of paddy rice stands in contrast with what has been found in the Changjiang Delta where small-holding family farms remain the dominant form of agricultural production even after the reforms. ${ }^{7}$

Viewed in a regional perspective, Nanhai is a case typical and illustra-

4. China, State Statistical Bureau, Zhongguo fenxian nongcun jingji tongji gaiyao (1991) (Statistical Abstract of China's County-level Rural Economies (1991)) (Beijing: Zhongguo tongji chubanshe, 1993), p. 242.

5. William Byrd and Lin Qingsong (eds.), China's Rural Industry (New York: Oxford University Press, 1990), pp. 82 and 356.

6. Zhao Duanzhang, "Nanhai moshi" ("The Nanhai Model"), in Wang Guanzheng and Zhang Bingsheng (eds.), Guangdong sixiaohu (The Four Little Tigers in Guangdong) (Guangzhou: Guangdongsheng gaodeng jiaoyi chubanshe, 1991), p. 141.

7. Philip Huang, The Peasant Family and Rural Development in the Yangzi Delta: 1350-1988 (Palo Alto, CA: Stanford University Press, 1990), pp. 18 and 305. 


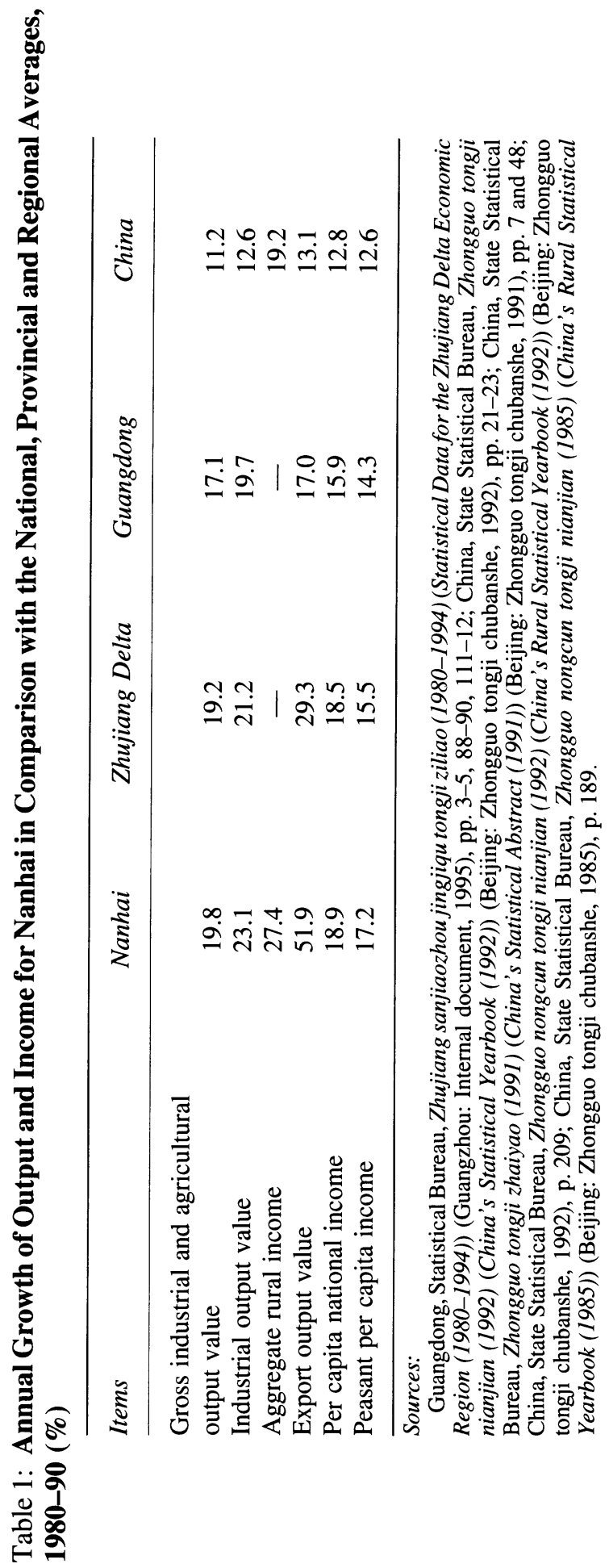




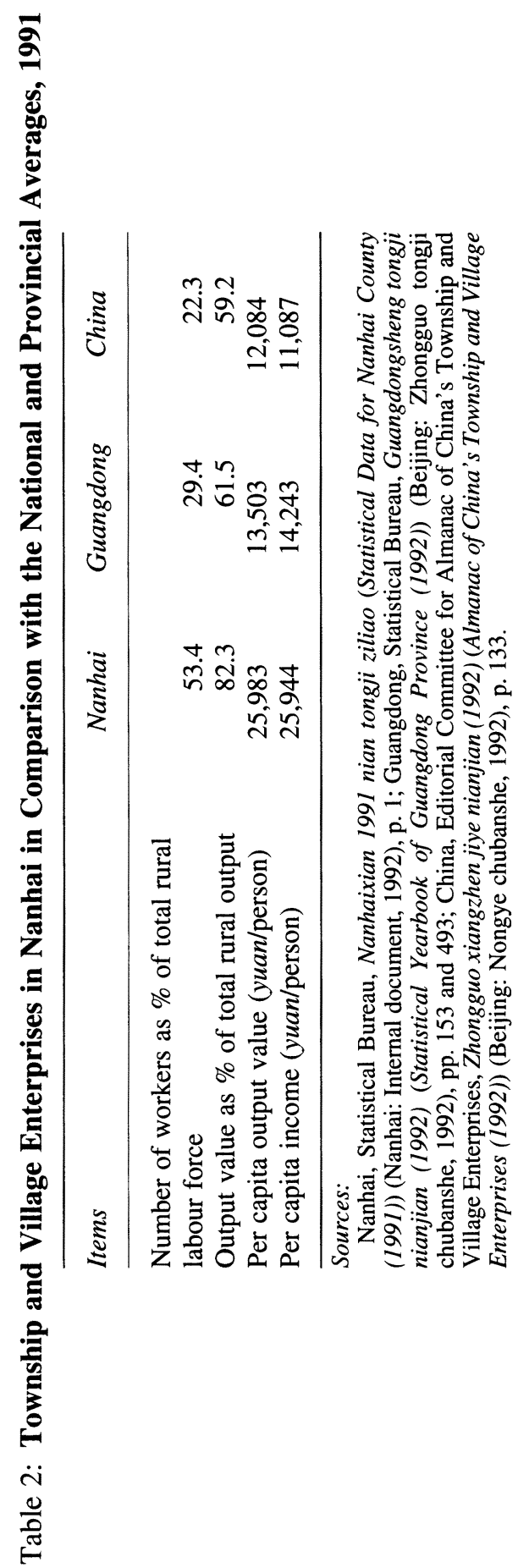




\section{Map 1: The Location of Nanhai in the Zhujiang Delta}

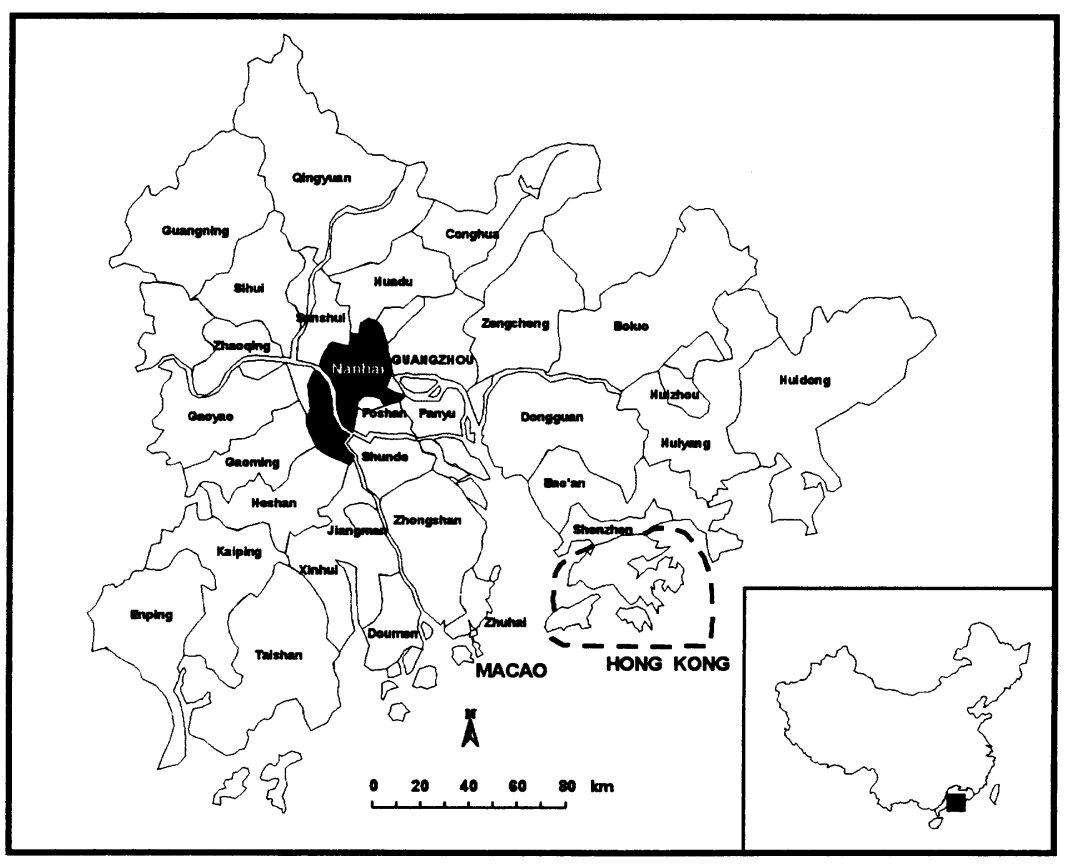

tive of the general geographic situation of the Zhujiang Delta. It is located in the centre of the delta region (Map 1), covers an area of over 1,100 square kilometres and had a total population of over one million in 1995. Its territory is composed of three main areas. The southern half of its land extends to the lower reach of the Zhujiang and is dominated by a human-made agricultural system of "mulberry dike and fish pond" (sangji yutang), a system popular in many areas of the delta for decades. ${ }^{8}$ Its central and eastern part is primarily flat plain suitable for the growing of paddy rice, vegetables and fruit. Located on the immediate outskirts of the cities of Guangzhou and Foshan, this area serves as a suburb for the two cities, producing many farm products for urban consumption. The northern part extends to the upper reaches of the North River (Beijiang) where landscape is relatively mountainous and agricultural production is dominated by the production of groundnut, sugar cane and livestock. From a geographical point of view, Nanhai is diversified enough to epitomize the general situation of the Zhujiang Delta.

This study examines the process of rural economic restructuring and geographic transformation in the post-reform Zhujiang Delta region, using Nanhai as a case. It begins with an overview of the historical background. This is followed by an analysis of the process of agricultural

8. Zhong Gongfu, "The mulberry dike-fish pond complex: a Chinese ecosystem of land-water interaction on the Pearl River Delta," Human Ecology, Vol. 10, No. 2 (1982), pp. 191-202. 
restructuring and rural industrialization since economic reforms were instituted in 1978. The geographic consequence of economic change is then assessed with specific reference to migration, land use and environmental degradation. Major findings are summarized and discussed in the final section.

\section{Historical Background}

Although Nanhai is distinguished by its remarkable record of postreform growth and development, it has gone through a historical process common to other economies in the Zhujiang Delta and elsewhere in the country. When economic reforms were initiated at the end of 1978, Nanhai was a county overwhelmingly rural with three quarters of its population earning a living from agriculture without the benefit of mechanization. ${ }^{9}$ The county was densely populated at 768 people per square kilometre which exceeded the provincial average by 468 persons and the national average by $658 .{ }^{10}$ Available farmland was so limited that cultivated land per capita was a mere $0.7 \mathrm{mu},{ }^{11}$ significantly less than either the provincial or national average. With limited farm land bearing a dense and growing population, underemployment was a long-standing problem. It has been estimated that on the eve of the reforms, about 40 per cent of Nanhai's agricultural labour force was unable to find jobs. ${ }^{12}$ As rural-urban migration was restricted, the surplus rural labour had to remain on farms for subsistence. Agricultural output did expand, but because of the large and growing population, labour productivity was low and little improvement occurred. The value of net output produced by farmers was a mere 549 yuan per labourer and rural per capita income was only 186 yuan in 1978. This situation, wherein agriculture had stagnated at a subsistence level, appears to fit neatly into the concept of "involutionary growth" or "growth without development" introduced by Philip Huang, which refers to a process whereby agricultural production expands but the marginal returns diminish. ${ }^{13}$

At the time, the people of Nanhai were preoccupied with the task of seeking self-reliance in food supply. Grain production was taken as the "key link" of the economy and there was little room for other economic pursuits such as sideline farming, trading, transportation and manufacturing. Such a single-sided production system which overemphasized the

9. Nanhai, Statistical Bureau, Nanhai 40 nian (1949-1988) (Nanhai's 40 Years (1949-1988)) (Nanhai: Internal document, 1989), p. 1.

10. Zhao Duanzhang, "Nanhai moshi," p. 141.

11. $1 m u=0.0667$ hectare $=0.1647$ acre.

12. Zhao Guanzhang, "Wuge lunzi yiqi zhuan" ("Driving forward on five wheels"), in Editorial Board of Guangzhou Daily (ed.), Shijian de guanghui (The Radiance of Practice) (Guangzhou: Guangdongsheng gaodeng jiaoyi chubanshe, 1988), p. 355.

13. The concept of involution was introduced by Philip Huang to describe a process wherein agricultural output expands, but labour productivity and per capita income improve little because of growing population pressure. See Huang, The Peasant Family and Rural Development, p. 13. 
rice crop produced little material for manufacturing. A peasant economy perpetuated at the subsistence level, generating no surplus for capital investment in the manufacturing sector. Moreover, Nanhai was financially under such rigid control by both the provincial government and the Foshan municipality, to which it was subordinate, that it was unable to initiate industrial development at the local level. Consequently, modern manufacturing had been virtually non-existent except for a few small rural workshops repairing or producing items for agricultural production - fertilizer, cement, farm tools and machinery, and irrigation pumps.

Prior to the reforms, urban development had suffered severely from a constant attack on urban commercial functions, a lack of funds for town construction and the government's restriction on rural-urban migration. The presence of Foshan city nearby had also brought much competition to Nanhai for urban development. As a result, Nanhai in the pre-reform period recorded an abnormally low level of urbanization, with less than a quarter of its population engaged in non-agricultural activities which took place mainly in rural market towns. Nanhai did not even have a county town until 1990 when a county capital was built in the market town of Guicheng. The town was quickly developed to acquire designated city status which was granted directly by the State Council two years later in 1992. Thus, despite its central location in the delta and excellent natural endowments, Nanhai had been unable to ignite the engine of economic development until the 1980s.

\section{Agricultural Development and Rural Industrialization}

The reform programmes initiated in December 1978 brought profound changes into the local economy. Although many factors were responsible for the transformation, from an institutional perspective four sets of policy change have underlined the process. First, the implementation of the Household Production Responsibility System provided great incentives for farmers to raise productivity. Secondly, adjustments of procurement prices for many farm products during the years from 1979 to 1986 helped raise farm income and motivated peasants to produce more. ${ }^{14}$ Thirdly, the opening up of commodity markets facilitated the transfer of resources in and out of the agricultural sector and accelerated agricultural specialization. Finally, the reformed system of taxation and local finance (caizhen baogan) has stimulated local enthusiasm for revenue generation and greatly fostered the growth of industrial activities because they can normally generate higher income and more job opportunities than agriculture.

14. For detailed discussion, see Robert Ash, "The evolution of agricultural policy," The China Quarterly, No. 116 (1988), pp. 529-555; Kenneth Walker, "Chinese agriculture during the period of the readjustment 1978-1983," The China Quarterly, No. 100 (1984), pp. 783-812; Carl Riskin, China's Political Economy: The Questfor Development since 1949 (New York: Oxford University Press, 1987), p. 285. 
The development of a market mechanism was especially important to the transformation of the local economy. The state monopoly purchase and marketing system (tongguo tongxiao), which lasted for three decades, was fundamentally reformed in 1985 to give free market forces a much larger role. The number of agricultural products that used to be purchased by the state was reduced from 118 to only 5, and manufactured products supplied and distributed by the state to peasants from 95 to 13. Prior to the reforms, the provision of daily necessities such as grain, cooking oil, meat, fish, sugar, cloth and soap was monopolized by the state through a rationing system under which consumers could not buy what they needed from the stores unless they had the purchasing tickets rationed by the state. This system covering about 40 basic commodities was abandoned in 1986. Moreover, the state no longer regulated prices for the sale of agricultural products so that the proportion of farm products sold at state-regulated prices dropped from an overwhelming 91.3 per cent in 1978 to only 23.9 per cent in 1986 , and the proportion sold at fluctuating market prices increased simultaneously from 8.7 per cent to 76.1 per cent. Similarly, after pricing of daily-use goods was aligned with the free market, the proportion of free market sales increased from a mere 2.8 per cent in 1978 to a predominant 86.5 per cent in $1986 .{ }^{15}$ With all of these changes, the state was no longer responsible for the purchase, supply and distribution of agricultural products and manufactured goods. Agricultural production was now regulated by market forces and farmers were able to respond to the demands of the market according to their own production capability. This has enabled them to specialize in crops which they perceive as profitable and for which they have a comparative advantage. It has also required them to be flexible in response to the changing demands of the market.

Agricultural development. From an ideological standpoint, the new policies outlined above are essentially an indication of the tacit laisserfaire attitude of the reformed central state in dealing with local economic affairs. Implementation of these policies has allowed free market forces to shape Nanhai's economy. One direct and immediate outcome of the reforms has been rapid diversification and commercialization of agriculture.

Once farmers were allowed to make their own production decisions and maximize their profits, they quickly took the initiative in responding to the demands of the market. Since the demand of the agricultural market covers a wide range of products extending beyond that of grain and since the cultivation of rice is generally less profitable than either the raising of fish or the planting of fruit trees, the first move that farmers made was to shift their focus away from rice cultivation to the production

15. Zeng Guangshang, "Zhujiang sanjiaozhou jingji tizhi gaige shinian huigu" ("A retrospect of economic reforms of the Zhujiang Delta"), in Editorial Board of Guangzhou Daily (ed.), Shijian de guanghui (The Radiance of Practice) (Guangzhou: Guangdongsheng gaodeng jiaoyi chubanshe, 1988), pp. 1-7. 
of other more profitable market-oriented commercial crops. Many rice fields were transformed into fish ponds or turned into orchards. Between 1980 and 1990, orchard area expanded by five times from 3,767 $\mathrm{mu}$ to $24,030 \mathrm{mu}$ and the fish pond acreage increased by 10,205 $\mathrm{mu}$ ( 9 per cent). At the same time, the amount of acreage in rice was reduced by 42,933 mu (10 per cent). ${ }^{16}$ Other commercial farming activities such as poultry-breeding, pig-rearing, and the growing of vegetables and flowers for urban consumption have also expanded rapidly. By 1990, traditional grain production no longer dominated agriculture. Its share of the total value dropped from 53 per cent in 1980 to only 34 per cent in $1990 .^{17}$

The restructuring of agricultural production has two salient features. First, it is shaped primarily by free market forces. This is evident from the allocation of farmland which is frequently changed according to the fluctuations of the market. When the market price for fish was first deregulated in 1981, for example, the area devoted to fish ponds increased substantially by $2,320 \mathrm{mu}$ (382 acres) in that year. Similarly, when the demand for fruit shot up in the mid-1980s, orchards suddenly expanded by $23,370 \mathrm{mu}(3,849$ acres $)$ in the two years of $1985-87 .^{18}$ Generally, once a particular crop is perceived as more profitable, farmers immediately decide to expand production of that crop until the economic returns diminish as the market becomes saturated. Thus, the cropping pattern and the type of agricultural activities being carried out, which used to be determined by the government, are now under the control of the market.

Secondly, the process of agricultural diversification and commercialization in Nanhai was greatly facilitated by its strong connections with large cities nearby and the possibility of exporting. Since the reforms, Nanhai has built a number of export production bases which specialize in the production of fruit, vegetables, pond fish and fowl. By 1987, ten such production bases had been built, covering an area of 340,000 mu $(55,998$ acres) thereby accounting for 40 per cent of the total farmland. They had generated an export revenue of US\$18.98 million which was about 70 per cent of Nanhai's total agricultural export. ${ }^{19}$ Some of these export bases are on a fairly large scale. For instance, the poultry farm in Shishan town covered an area of 1,544 $\mathrm{mu}$ (254 acres). The vegetable farm in Lishui town was even bigger, covering an area of 5,000 mu (823 acres) and producing 20,000 tons of high quality vegetables annually. These huge farms were equipped with modern agricultural machinery, most of it imported. Taking full advantage of economies of scale, they have generated a net income higher than that of individual smaller farms. Such a

16. Nanhai, Statistical Bureau, Nanhaixian 1990 nian tongji ziliao (Statistical Data for Nanhai County (1990)) (Nanhai: Internal document, 1991), p. 15.

17. Ibid. p. 9.

18. Nanhai, Statistical Bureau, Nanhai 40 nian, p. 10.

19. Nanhai, Work Team, "Nanhaixian cujin nongye guimo jingying de qingkuang he mianlin de wenti" ("Progress and problems in the promotion of agricultural production at a sizeable scale in Nanhai county”), Nongcun yanjiu (Rural Studies), Vol. 30/31 (1988), pp. 8-9. 
new agricultural production system, called by the local people "management on a sizeable scale" (shidu guimo jingying), is becoming popular in the countryside of Nanhai and other places in the delta region. This pattern of agricultural development where large-scale modern farming is gradually taking shape stands in sharp contrast to the pattern of persistent small-holding agriculture in the lower Changjiang Delta. ${ }^{20}$ It appears that the existence of large urban centres nearby has enabled agriculture to be diversified, commercialized and modernized more rapidly here than elsewhere.

While many rice fields are being turned over for the production of market-oriented commercial agriculture, farmers cannot completely cease rice production because they still have to meet the contracted minimum rice quota in order to keep the land assigned to it under the household responsibility system. Farmers in Nanhai, however, have found ways to meet their grain quotas while engaging in other more profitable activities. For example, some farmers whom I interviewed in Dali town have negotiated with local officials and since 1984 have been allowed to make cash payments in lieu of the rice quota. Other farmers began to hire people from the poorer areas outside the delta region to cultivate their rice crops, thus meeting their quotas, while they themselves took higherpaying jobs off the farm.

Another solution that has become increasingly popular is to let those farmers who are not good at rice cultivation subcontract the land they were allocated to farmers who are "rice-growing specialists" (zhong tian neng shou). In some localities such as the Dong village of Pingzhou town, all rice fields, with an area of $145 \mathrm{mu}$ (24 acres), were contracted to the household of farmer Zhu Jingcheng, a rice cultivation specialist. Zhu and his family then used their expertise to the greatest extent and made a higher profit from rice cultivation than they otherwise could have made. The grain produced by Zhu's household was then sold to the local villagers for their own consumption and for meeting their grain quotas required by the government. By so doing, other farmers of the village were freed from the production of rice and were able to do whatever they felt was more profitable and suitable to their own expertise. In this way, agricultural production has become increasingly specialized. ${ }^{21}$

The process of agricultural specialization has gone beyond the sphere of production and has begun to affect the marketing and circulation of farm products. Under the household responsibility system, farmers could sell their surplus products after the contracted quotas were met. During the harvest season, many farmers found it more efficient either to sell the farm products at once to a middle-man who would resell them at retail prices, or simply to hire someone with a vehicle to transport their goods to market. New trade and transport specialists have therefore emerged to take advantage of these opportunities. Some individuals bought a tractor or motor-cycle and became specialized in transporting goods. When

20. Philip Huang, The Peasant Family and Rural Development, p. 18.

21. Unstructured interview conducted in October 1992. 
travelling around the countryside of Nanhai, one often finds a group of motor-cyclists or tractor drivers waiting at the entrance to a rural village or town for possible transport jobs.

Diversification and specialization of agricultural production have also manifested themselves in the diversification of occupation for the peasant family. In the pre-reform era, all adult workers of a family had to work for the production team in order to get sufficient "working points" (gong $f e n$ ), based on which grain would be allocated to the family by the team. Besides being part of the enduring process of involution, farmers had no other option regardless of talent or inclination. Under the Household Production Responsibility System, two people in the family, often the elderly and the housewife, can easily handle all the farm work on the field the household is allocated. Other family members, the husband and his sons or daughters, are free to take more lucrative jobs elsewhere. Consequently, it is not uncommon to find the members of a peasant family having a variety of occupations including farming, manufacturing, transport, construction and trading.

Along with the diversification and specialization of agriculture, traditional cultivation of rice has begun to enter a new stage of mechanization. In the pre-reform era, mechanization made little progress despite the rhetorical campaign of the central government. Ironically, it was after the de-collectivization of the agricultural production system that the cultivation of rice became spontaneously mechanized. This process can be illustrated by the development of the rural district of Liangjiao where I did my field work in 1992.

Located in the midst of a flat plain between the cities of Foshan and Guangzhou, Liangjiao district is traditionally an area for paddy rice production. It consisted of two villages and had a total population of 2,456 in 1992. The implementation of the Household Production Responsibility System in the early 1980s divided Liangjiao's 1,300 $\mathrm{mu}$ of cultivated land into small tracts for individual peasant households. While the de-collectivization of farming did provide incentives for farmers to work harder for higher personal gains, it made it difficult for an efficient utilization of the irrigation system and other agricultural machinery. In 1991, local cadres of Liangjiao district decided to do a little experiment. From the existing cultivated land of $1,336 \mathrm{mu}$, they took $300 \mathrm{mu}$, one tenth of the total, to form a large farm for rice cultivation. The farm was looked after by 12 experienced farmers who were good at rice production. A well-regulated irrigation system was built. High quality grain seeds were sown. Modern farming machinery imported from Germany was used. The experiment turned out to be a great success, with a grain yield exceeding 500 kilograms per $m u$. The experimental farm was then expanded into a huge one covering an area of 1,000 mu (164.7 acres). For better management, an Agricultural Development Company was formed in 1992. The company hired 20 farmers who worked eight hours a day, six days a week for a salary of 500 yuan a month. A bank loan was made available to the company by the Bank of Agriculture for purchasing machinery, grain seed and fertilizer, and for other farm infrastructure 
investment. The company signed a contract with the district of Liangjiao which required it to meet a grain production quota of 850 kilograms per $m u$. Anything produced above the quota could be retained by the company.

As a result of mechanized and intensive farming, the grain yield far exceeded the contracted quota by over 100 kilograms per $m u$ in the spring crop of 1992 which transferred into a net income of 146,080 yuan for the company in the first half of the year. With double cropping being practised, the company was able to make a net income of 290,000 yuan a year. ${ }^{22}$

To what extent and in what manner has agricultural restructuring contributed to the process of geographic transformation? My field investigation in Nanhai suggests that it is not agricultural restructuring alone but its interaction with rural industrial development that has shaped the spatial pattern of change in population redistribution and land use transformation. More specifically, agricultural restructuring has interacted with industrial development in the village and township levels in the following ways.

First, diversification and commercialization of agriculture have significantly raised rural income and provided substantial capital to facilitate rural industrial development. The financial advantage of cashcrop farming over rice cultivation has been remarkable. According to a survey conducted by the Agricultural Commission of Nanhai in 1986, rice cultivation could generate a net income of only 195 yuan per $m u$ which was much lower than the net income generated by fish raising (546 yuan/mu) and sugar cane planting (303 yuan/mu, not to mention the growing of vegetables, fruit or flowers which normally produce a net income of several thousand yuan for the same area. ${ }^{23}$ The shift of production focus from traditional cheap grain to more profitable cash crops has, therefore, enabled the value of agricultural production to rise substantially. Rural per capita income rose sharply from 350 yuan in 1980 to 1,701 yuan in 1990 . The income generated by peasants in 1990 on a per capita basis was significantly higher than either the regional average of the delta (1,288 yuan/person) or the provincial average of Guangdong (1,043 yuan/person). It was even higher than that of other economically advanced counties such as Shunde (1,500 yuan/person), Dongguan (1,359 yuan/person) and Zhongshang (1,531 yuan/person) ${ }^{24}$

With a growing peasant income, personal savings shot up from a total of 52.12 million yuan in 1978 to 1.658 billion in 1987. Per capita saving deposits rose dramatically from 136 yuan in 1980 to 4,359 yuan in 1990 which again was much higher than the regional average of the delta $(2,713$ yuan/person) and the provincial average of Guangdong $(1,205$

22. Unstructured interview conducted in October 1992.

23. Nanhai, Agricultural Commission, Guangdongsheng Nanhaixian 1986 niandu nongchanpin chengben diaocha ziliao (Investigation Materials on the Cost of Agricultural Production in Nanhai County 1986) (Nanhai: Internal document, 1987), p. 10.

24. Guangdong, Statistical Bureau, Zhujiang sanjiaozhou guomin jingji tongji ziliao (1980-1991) (National Economic Statistical Data for the Zhujiang Delta (1980-1991)) (Guangzhou: Internal publication, 1992), pp. 175, 135, 139. 
yuan/person). Such sizeable bank savings, in combination with overseas remittances estimated at US\$69.72 million during the ten years of 1978 87, have provided a large amount of capital for investment in the industrial sector. In 1986, for instance, 900 million yuan was provided through bank loans for the development of industries in the villages and townships of Nanhai. ${ }^{25}$

Secondly, the specialization and mechanization of agricultural production have released a great number of surplus rural labourers who have turned to rural industry for employment. The intrusion of free market forces has greatly motivated peasants to increase labour productivity so as to maximize personal gain. Data from Nanhai have shown that labour productivity has, indeed, significantly improved since the reforms, with agricultural value per labourer rising from 1,005 yuan to 4,650 yuan at the 1980 constant price during the years $1980-90 .{ }^{26}$ In the rural district of Liangjiao where field work for this study was conducted, before mechanization the farming of the available $1,336 \mathrm{mu}$ required the entire labour force of 1,316 people, but after mechanization, cultivation of rice on $1,000 \mathrm{mu}$ required only 20 experienced farmers. When these farmers and other administrative staff as well as emigrants were deducted, a total of 1,184 peasants, over 90 per cent of the labour force, were no longer needed in the farm. ${ }^{27}$ For Nanhai as a whole, it was reported that by 1987 , over 60 per cent of its rural labour force had been removed from agricultural production. ${ }^{28}$ These unemployed peasants had to find nonfarm employment in the townships or villages of the countryside. Thus, the mechanization and specialization of agriculture have generated a large amount of potential manpower for the development of rural industries.

Thirdly, commercialization and mechanization of agriculture have raised peasant demand for more manufactured goods, including not only agricultural equipment, machinery and other supplies for production purposes but also many consumer products, such as motor-cycles, televisions, electric fans, washing machines and refrigerators. The influence of Hong Kong through radio and television has further stimulated a desire for modern consumer goods among peasants. State factories in large cities were encouraged to meet this new demand, but after three decades of production following the Soviet model which overemphasized heavy industry, it is difficult for the big old plants in large cities to convert their machinery and retrain workers for the production of new consumer goods. By comparison, numerous small-scale rural industries can respond with greater speed and flexibility in spite of their unsophisticated technol-

25. William Byrd and Lin Qingsong (eds.), China's Rural Industry (New York: Oxford University Press, 1990), p. 78.

26. Nanhai, Statistical Bureau, Nanhai 40 nian, p. 5; Nanhai, Statistical Bureau, Nanhaixian 1990 nian tongji ziliao, p. 10.

27. Dali Town, Nanhaixian Dalizhen Lianjiao guanliqu tuixing liangshi shengchan qiye jingying de shiyan fang 'an jiqi shexiang anpai (A Proposal and Arrangement For Promoting the Enterprization of Food Grain Production in Lianjiao District, Dali Town, Nanhai County) (Nanhai: Internal document obtained during unstructured interview, 1992), p. 5.

28. Zhao Duanzhang, "Wuge lunzi yiqizhuan," p. 355. 
ogy. Thus the increasing demand of peasants for new consumer goods has directly fuelled the rapid growth of consumer industry in the countryside.

Finally, diversification and specialization of agriculture have revitalized the commercial function of small towns which are sparsely distributed over the countryside. As the surplus of the market-oriented farm goods increased, rural fairs and markets have not only been re-opened but also held more frequently than ever before to meet the demand of local peasants for buying and selling. The total value of market sales for Nanhai rose from 326.25 million yuan in 1980 to 16.45 billion yuan in $1990 .^{29}$ Many markets are constantly expanding and some have begun to specialize in the trading of certain farm goods or commodities. For example, the poultry market in Dali town was one of the first and largest specialized markets in Guangdong province. Its sales' volume reached 4,000 fowl and 13,000 kilograms of vegetables per day. ${ }^{30}$ The revitalization of the commercial function of small towns as a result of agricultural commercialization has become a significant impetus promoting the development of these towns. ${ }^{31}$

It may be argued from the foregoing analysis that the diversification, specialization and commercialization of agriculture, which occurred at the grass-roots level of the local economy, have significantly contributed to the process of rural industrialization, although the restructuring of agriculture per se did not directly result in major spatial development. The two processes of agricultural restructuring and rural industrialization have been so closely intertwined that it would be highly inappropriate to isolate one from the other. In this regard, the experience of Nanhai is distinct from that of other parts of the nation where market farming was unable to boost rural industrial development because of limited access to overseas international markets. ${ }^{32}$ Nanhai, however, is similar to other parts of the country in that industrial development at the township and village level has been the most powerful force directly shaping the spatial pattern of population redistribution, land use and town growth in the post reform era.

Rural industrialization. The rapid growth of rural industry at the township and village level since economic reforms has been a national phenomenon, but rural industrialization in Nanhai is distinguished by its magnitude and approach. Before the pattern of rural industrialization is assessed, it is necessary to clarify the local administrative structure as it has significant implications for the growth and distribution of rural industry.

29. Guangdong, Statistical Bureau, Guangdongsheng xianshiqu guomin jingji tongji ziliao (1980-1990) (National Economic Statistical Data for Cities and Counties of Guangdong Province (1980-1990)) (Guangzhou: Internal publication, 1991), p. 173.

30. Zhao Duanzhang, "Nanhai moshi," p. 169.

31. See Laurence J. C. Ma and Chusheng Lin, "Development of towns in China: a case study of Guangdong province," Population and Development Review, Vol. 19, No. 3 (1993), pp. 583-606; George C. S. Lin, "Small town development in socialist China: a functional analysis," Geoforum, Vol. 24, No. 3 (1993), pp. 327-338.

32. See Philip Huang, The Peasant Family and Rural Development, p. 17. 
The administrative system in Nanhai consists of five basic components, in a descending order of county (xian), township (zhen), administrative district (guanli qu), village (cun) and village community (cunmin weiyuanhui). The county has the highest authority in managing local economic affairs including personnel appointment, tax collection and budget allocation. A number of townships have recently been created to replace rural communes that existed in China from 1958 to 1984. On average, a township in Nanhai has a population of 55,000 and an area of 68 square kilometres. A typical township has a town seat which is normally accorded a designated town status, although the overall population and land area of the township are predominantly agricultural in nature. Below townships are several administrative districts formed in 1984 to replace brigades. A typical district has a population of several thousand and usually consists of a couple of villages which were formerly production teams. At the bottom of the hierarchy are village communities which are established primarily for census and organizational purposes. These communities have lost their economic functions as a result of the implementation of the production responsibility system.

In all, Nanhai had 17 townships, 242 administrative districts and 1,406 village communities in 1990. Under this administrative framework, rural industry or township and village industry (xiangzhen gongye) is actually the descendant of former commune and brigade industry (shidui gongye). The term "rural industry," however, is used in this study because it includes not only those industries that are owned by townships and villages but also those owned by private partnerships or individual households which have become increasingly important in the delta region, especially in Nanhai.

Small-scale rural industry, as a means of aid to agricultural production, had existed before economic reforms were introduced in 1978, but such industries had never played a major role in the local economy. Under the then prevailing policy which overemphasized grain production at the cost of other non-farm activities, the county government of Nanhai had even limited the growth of rural industries by ruling that commune and brigade enterprises should not hire more than 10-15 per cent of the local labour force.

It was not until the early 1980s that rural industry was allowed to flourish. In 1980, the county government of Nanhai noted that in one commune where industrial enterprises were tolerated and allowed to develop freely, peasant income had become higher and increased more rapidly than elsewhere. County officials reacted with a positive attitude, encouraging commune and brigade enterprises to develop across the county. Local people quickly seized the opportunity, and one year later 71 per cent of Nanhai's production teams started their own industrial enterprises. These remained collectively owned until 1983 when the production responsibility system was introduced to decollectivize production. Many enterprises were leased or sold to individuals for private management. In that one year, the aggregate value of the fixed assets of production teams dropped from 158 million yuan to 134 million yuan 
while the value of privately-owned fixed assets rose from 16 million to 104 million yuan. ${ }^{33}$

The privatization of industrial enterprises linked investment and labour input directly with personal gain and thus greatly motivated peasants to run factories efficiently and successfully. As a result, rural industry expanded rapidly to become a major pillar of the local economy. In March 1984, the commune-brigade-team system was officially dismantled and the "commune and brigade industry" (shidui gongye) was renamed the "township and village industry" (xiangzhen gongye).

The growth of rural industry since the reforms and especially since 1984 has been spectacular. Gross income generated by rural industry increased by over 13 times during the decade of the 1980s from 342.4 million yuan in 1980 to 4.67 billion in $1990 .{ }^{34}$ The share of rural industry in the total industrial production of the county rose from less than a quarter in 1978 to 66.56 per cent in $1991 .^{35}$ In 1978 , peasants who were engaged in industrial and sideline production accounted for 25.4 per cent of the labour force. By 1991, a total of 246,153 jobs had been generated by the rural industrial sector alone, accounting for 60.88 per cent of the labour force. The tax revenue generated by the collectively and privately owned enterprises, most of them industrial, accounted for 70 per cent of the total tax revenue of the county in 1988, far exceeding that of the state sector which was only 27 per cent. ${ }^{36}$ Obviously, rural industry has become the backbone of the local economy and has played a decisive role both in meeting the rising demand for consumer goods and in competing with state-owned industry.

Rural industries developed in Nanhai were predominantly labourintensive and market oriented. By far the largest group of factories were in textiles and apparel, in which Nanhai has traditional strength. Since silkworm cocoon used to be a major agricultural product of Nanhai, it is not surprising that silk processing and, later, textiles became the chief industry. The first modern silk mill in China was built in Xiqiao town at the turn of this century. By 1992 there were more than a thousand textile factories in Nanhai, with fixed capital assets of one billion yuan and over 20,000 textile machines. ${ }^{37}$ These factories used a variety of materials including polyester fibres, cotton and silk, and covered all phases of the production process. Their production capacity exceeded 200 million metres of cloth a year. The next largest group of factories focused on metal manufacturing, in which local people and those in Foshan city nearby have historical strengths. With technical assistance from Germany, Italy and Japan, 82 factories have been built since 1986, including

33. Byrd and Lin Qingsong, China's Rural Industry, p. 152.

34. Nanhai, Statistical Bureau, Nanhaixian 1990 nian tongji ziliao, p. 13.

35. Nanhai, Bureau of Township and Village Enterprises, Nanhaixian xiangzhen qiye jiben qingkuang (Basic Statistical Information for the Township and Village Enterprises in Nanhai County) (Nanhai: Internal document, 1992), p. 3.

36. Nanhai, Statistical Bureau, Nanhai 40 nian, p. 72.

37. Yang Jicheng, Wuge lunzi yiqi zhuan - Nanhaixian fazhan xiangzhen qiye shijian moshi (Driving Forward on Five Wheels: Experience of Township and Village Enterprise Development in Nanhai County) (Nanhai: Internal document, 1992), p. 8. 
a modern one producing thin aluminium metal, the only one of this type in southern China. ${ }^{38}$ The third largest area of concentration was in ceramic tiles, for which Nanhai has plenty of material resources and an excellent tradition of production. Its expansion coincided with the booming of real estate in Guangdong and other parts of China, thereby opening a large market. By 1992, Nanhai had 59 tile factories and over 100 ceramic production lines, with a total production capacity of 50 million square metres of tile per year and a nation-wide sales force.$^{39}$ In addition to these three sectors there were numerous small factories which produced all sorts of household consumer goods such as toys, shoes, watches, cans, wine, electric fans and micro-wave ovens. Most of the production was to satisfy the growing demand of domestic markets, but some products, particularly toys and shoes, were manufactured based on capital investment and technology from Hong Kong and were mainly for export.

There are several features associated with the development of rural industry. First, many factories in the townships and villages were fairly small. Data obtained from local authorities indicated that there were 10,865 industrial enterprises at the township and village level in 1991 . These varied in size and type, but on average a factory employed only 22 workers which is fairly small by Chinese standards. ${ }^{40}$ This small size made it difficult to achieve economy of scale. It has, however, allowed for great sensitivity and adaptability to changing market demands. Geographically, these small-sized factories can be located almost anywhere as they do not require massive infrastructure investment. Thus it is not uncommon to find small factories dotted across the countryside, sometimes in the middle of rice fields.

Secondly, while rural industries have flourished at all levels of the rural-urban hierarchy since the reforms, they have emerged primarily from the grass-roots level of the countryside. When the production of rural industries is broken down according to the four major ownership forms classified by local authorities, industrial enterprise at the village level has stood out as the leading player in production and in employment generation (Table 3), with enterprises developed by townships, individuals and private partnerships lagging behind. When other enterprises, whether state-owned, foreign-owned or joint ventures, are included for comparison, the contribution of village industrial enterprises to total industrial production remains outstanding. They produced 40 per cent of the total industrial output value in 1991, far more than either the 14 per cent share of the state sector, the 38 per cent of the township enterprises or the 6 per cent of the foreign firms or joint ventures. ${ }^{41}$ Such a pattern of production suggests that industrial development is primarily shaped by

38. Unstructured personal interview conducted in October 1992.

39. Yang Jicheng, Wuge lunzi yiqi zhuan, p. 9.

40. Nanhai, Bureau of Township and Village Enterprises, Nanhaixian xiangzhen qiye jiben qingkuang p. 5.

41. Nanhai, Statistical Bureau, Nanhaixian 1991 nian tongji ziliao (Statistical Data for Nanhai County (1991)) (Nanhai: Internal document, 1992), p. 44. 
Table 3: Industrial Ownership Structure for Nanhai, 1991 (\%)

\begin{tabular}{lrrc}
\hline $\begin{array}{l}\text { Ownership } \\
\text { type }\end{array}$ & $\begin{array}{c}\text { Output } \\
\text { value }\end{array}$ & Income & Employment \\
\hline Township & 39.02 & 38.60 & 28.04 \\
Village & 44.73 & 44.95 & 46.67 \\
Partnership & 4.30 & 4.36 & 7.64 \\
Individual & 11.95 & 12.09 & 17.65 \\
Total & 100.00 & 100.00 & 100.00 \\
\hline
\end{tabular}

Source:

Nanhai, Bureau of Township and Village Enterprises, Nanhaixian xiangzhen qiye jiben qingkuang (Basic Statistical Information of Township and Village Enterprises in Nanhai County) (Nanhai: Internal document, 1992), pp. 1-52.

the enterprise of rural villages. It also suggests, from the production perspective at least, that the chief player of rural industrialization was neither the state sector nor the privately owned individual enterprises, but the collectively owned village industries.

Thirdly, the development of rural industry is essentially spontaneous and self-sustained, driven primarily by local initiative. Capital investment in the rural industrial sector was largely mobilized from local resources through a number of channels. The local branches of the Agricultural Bank of China held the bulk of household saving deposits of the county, and have provided a considerable number of bank loans to rural communities for the setting up of industries. It was estimated that during $1980-86$, the Bank of China lent US\$7.8 million, mostly short term, to rural industrial enterprises in Nanhai. In 1986, such industries in Nanhai obtained 900 million yuan of bank loans through various channels. ${ }^{42}$ Remittance from friends and relatives in Hong Kong and overseas have also contributed to capital investment in the rural industrial sector. By contrast, the state was not actively or directly involved in spite of its rhetoric encouragement. In fact, the state contributed only 16 per cent to the total investment in fixed assets in 1991. The remaining 84 per cent was realized by the collective and private sectors through various local initiatives. ${ }^{43}$ With regard to raw materials, local people have reported that they no longer depend on state planning for their needs and that mandatory state plans cover only one-eighth of their total industrial output. Even the technology and production methods were obtained by local people through their contacts with firms in Hong Kong and overseas. Thus, except for being a property owner who maintains the power of tax collection and personnel appointment, the state has contributed little to the provision of capital, technology or raw materials for rural industrial

42. Byrd and Lin Qingsong, China's Rural Industry, p. 78.

43. Nanhai, Statistical Bureau, Nanhaixian 1991 nian tongji ziliao, p. 76. 
development. It is local initiative, mainly at the village level, that has driven the process of rural industrialization.

\section{Geographical Transformation}

The rapid growth of rural industry has significantly facilitated the process of structural and spatial transformation. The most remarkable effect of industrial development in the countryside has been the creation of employment to absorb surplus rural labour released from agricultural production as a result of increased labour productivity. It was reported that during 1985-91 an average of 13,534 jobs were created each year by rural industries. ${ }^{44}$ Whereas in 1978 , some 40 per cent of the agricultural labour force were unable to find jobs outside agriculture, by 1986 Nanhai, for the first time in its history, had a labour shortage so that outside workers had to be recruited to control rising labour costs. Consequently, Nanhai was changed from a county of out-migration because of underemployment in the pre-reform period into a destination favoured by immigrants. When the first national population census was conducted in 1982, Nanhai recorded a net population loss of 1,382 people. This pattern reversed in 1990 when immigrants out-numbered emigrants by 99,893 people. $^{45}$ Thus, the local economy was fundamentally transformed from one of underemployment, or "involutionary growth," into one of growing wealth, improved labour productivity and abundant employment opportunities, or "transformative development." 46 The driving force underlying this process was clearly rural industrialization.

More importantly, the development of rural industry enabled a growing number of peasants to "enter the factory without moving into the city" (jinchang bujincheng) or "leave the soil but not the village" (litu bulixiang).$^{47}$ According to population census data obtained from Nanhai, the occupational structure of the local population in 1982 was predominantly agricultural. A majority (58.85 per cent) of the population was engaged in agricultural production and the number of factory workers accounted for no more than 29 per cent. Eight years later in 1990, the situation was fundamentally changed. The proportion of factory workers jumped to 41 per cent whereas the agricultural share dropped to 38.94 per cent. $^{48}$ Obviously, a considerable number of farmers left the soil and

44. Nanhai, Bureau of Township and Village Enterprises, Nanhaixian xiangzhen qiye jiben qingkuang, p. 3.

45. Nanhai, Population Census Office, Guangdongsheng Nanhaixian disici renkou pucha baogaoshu (A Report of the Fourth Population Census of Nanhai County) (Nanhai: Internal document, 1992), p. 22.

46. Development is seen here as a concept virtually different from growth. Growth only means increase in output, whereas development means improved productivity and per capita income. Growth may occur with or without development. See Dudley Seers, "What are we trying to measure?" in Nancy Baster (ed.), Measuring Development (London: Frank Cass, 1972), pp. 21-36; Also see Huang, The Peasant Family and Rural Development, pp. 13-18.

47. Samuel P. S. Ho, Rural China in Transition (Oxford: Clarendon Press, 1994).

48. Nanhai, Population Census Office, Guangdongsheng Nanhaixian disici renkou pucha baogaoshu, p. 52. 
entered the factory. It should be noted that most of the peasants who have entered factories continued to live in the countryside, as is evident when the number and proportion of factory workers are compared with those of town residents. According to the 1990 population census, while there were 248,672 factory workers in Nanhai, 41 per cent of its total population, there were only 172,557 town residents, 16.85 per cent. ${ }^{49}$ As not all town residents were engaged in manufacturing, the actual difference between the total number of factory workers and those who resided in the towns must be substantial. Thus, a considerable number of factory workers actually worked and lived in the countryside. This finding is consistent with that of the previous analysis which revealed that township enterprises accounted for only a small portion of the industry and that the focus of industrial development was in the rural villages. This pattern suggests that the success of industrial development in the countryside was able to deter the rural exodus into the city. It further suggests that rural industrialization is a crucial factor to explain why there is no significant population concentration in the large cities of the Zhujiang Delta despite rapid industrial development. ${ }^{50}$

The development of rural industry has also contributed to changes in land use. As manufacturing is perceived as a desirable activity that can generate more jobs and higher income than rice cultivation, a considerable amount of farmland has been transformed into paved industrial sites. It was reported that from 1982 to 1990 , a total of $3,597.15$ acres of farmland were taken by non-agricultural development. Of this, industrial expansion accounted for about 32 per cent, transport development about 21 per cent, residential land use 19 per cent and other construction purposes the remaining 26 per cent. ${ }^{51}$

It is not possible to show exactly how much industrial land expansion was in the countryside and how much was in towns. It is known, however, that most factories were built in rural villages rather than in existing towns. Of the 11,109 industrial enterprises that have been built, 10,524 or 94.7 per cent were found in or below the village level..$^{52}$ Most of these were located either at the entrance to a village or along the road that passes by the village, as such locations allow for the easy transport of both raw materials and finished products. Some of them could be found on the edge of the village immediately next to rice fields. By building a factory locally within the jurisdiction of the village, factory owners, that is peasants of the village, were able to save a considerable amount of land rent required for city or town sites. Such a location was also easily accessible to the local villagers. As a result of rapid industrial growth at the village level, there is a growing mixture of land use by the industrial and agricultural sectors in the countryside. Rural industrialization has thus gradually created a new landscape wherein industrial and

49. Ibid. pp. 26, 52.

50. George Lin, Red Capitalism in South China (Vancouver: UBC Press, 1997).

51. Chen Lie, Nanhaishi tudiliyong zhongti guihua (A Master Plan for Land Use in Nanhai) (Nanhai: Internal document, 1992), p. 5.

52. Nanhai, Statistical Bureau, Nanhaixian 1991 nian tongji ziliao, p. 44. 
agricultural or urban and rural land uses stand side by side, leading to a blurring of the rural/urban distinction. ${ }^{53}$

In addition to changes in population distribution and land use, rural industrialization has resulted in some significant environmental consequences which are usually overlooked by scholars and planners who tend to focus on environmental problems in large cities. As revealed in the analysis above, industrial production in Nanhai was mostly on a small scale with unsophisticated technology for simple manufacturing. Many of these factories did not have the necessary facilities and advanced techniques for the proper treatment or recycling of industrial waste simply because they were too small to afford them. Their location, virtually in the "grey area" of the countryside where environmental regulations were much looser than in the city, has further accentuated unregulated and untreated disposal of industrial waste. Moreover, as hazardous and polluting industries were no longer tolerated in large cities, Nanhai, which is a suburban county immediately next to the cities of Foshan and Guangzhou, has increasingly become a major target for relocation of heavily polluting industries including sugar refining, cement production, textile printing and dyeing, electroplating and aluminium processing. Consequently, much of the Nanhai area has been treated as a dumping ground for various waste materials generated by industrial production.

An early survey conducted by the local environmental agency revealed that in 1988 industrial production released a total of 4,166.3 tonnes of sulphur dioxide, nitrous oxide, carbon dioxide and particulates into the air. ${ }^{54}$ The emission of these hazardous materials skyrocketed to $60,737.56$ tonnes in 1990 as a result of the rapid growth of rural industry. ${ }^{55}$ At the same time, the amount of waste water discharged from industrial production jumped from 52.7085 million tonnes to 135.637 million tonnes. Most of the waste gas emission came from the combustion of poor quality coal which provided almost all the energy and electric power for rural industry. The waste water was generated primarily by those factories that were involved in sugar refining, paper pulp processing, textile dyeing and electroplating. It was often released directly into streams which provided water for rice or vegetable fields, and even into fish ponds, without proper treatment or purification, leading to serious contamination of farmland and crops. In Lidong district of Dali town, for instance, among the $90 \mathrm{mu}$ of fish ponds, $70 \mathrm{mu}$ were contaminated. On average, one out of every five $m u$ of cultivated land in Nanhai was found to have been contaminated. ${ }^{56}$

53. See Terry McGee, "The emergence of desakota regions in Asia: expanding a hypothesis," in Norton Ginsburg et al. (eds.), The Extended Metropolis: Settlement Transition in Asia (Honolulu: University of Hawaii Press, 1991), pp. 3-25.

54. Nanhai, Environment Monitoring Station, Nanhaixian huanjing zhiliang nianbao (1988) (Annual Report on the Environmental Quality of Nanhai County (1988)) (Nanhai: Internal document, 1989), p. 69.

55. Nanhai, Environment Monitoring Station, Nanhaixian huanjing zhiliang nianbao (1990) (Annual Report on the Environmental Quality of Nanhai County (1990)) (Nanhai: Internal document, 1991), p. 33.

56. Guangdong, Foshan, and Nanhai, Joint Investigation Team, "Guanyu nongcun tudi zhidu jianshe de jige wenti" ("Several issues on establishing rural land system"), Nongcun yanjiu, Vol. 39 (1989), pp. 16-17. 
Similarly, increasing waste gas emission has caused severe air pollution and resulted in some damage to the local ecosystem. Acid rain has been reported to be more frequent than ever before, with occurrence rising significantly from 1.6 per cent in 1986 to 17.49 per cent in $1990 .^{57}$ Some of these ecological changes could be irreversible and disastrous.

While rural industrialization has brought considerable wealth for peasants, it has simultaneously degraded the environmental quality of life for the local people and reduced the sustainability of the environment for further economic expansion. Given that the local economy is currently growing and that the people of Nanhai are all preoccupied with seeking higher profits at any cost, it is unlikely that they will stop exploiting natural resources or make sacrifices to preserve a sustainable environment for the sake of the future generations. On the contrary, as industrial and agricultural production continue to expand, natural resources and the environment will have to suffer even further to satisfy the ever-growing demand of the local people for wealth and consumer goods. Therefore, rural industrialization, which is essentially unplanned, small scale and intimately related with the natural environment, has been and will continue to be one of the most powerful forces changing not only the space economy of the region but also the natural ecosystem for human habitat.

\section{Conclusion}

The Chinese countryside has been undergoing a significant process of profound economic and geographic transformation since the reforms. While it is generally known that the reforms have brought much wealth and prosperity for Chinese peasants, the operating mechanism of this process and its subsequent geographic consequences remain little understood. This case study of Nanhai reveals that the transformation of the rural economy in the Zhujiang Delta was characterized by two simultaneous processes: agricultural restructuring and rural industrialization. These are found to be so closely intertwined that it would be highly inappropriate to isolate one from the other.

Although the penetration of free market forces has led many profitable non-agricultural activities to assume an increasingly important position in the peasant economy, agriculture as a traditional economic sector was not completely conquered by the newly emerging, modern, urban-based industries. Instead, the experience of Nanhai demonstrated that agriculture was able to be restructured to meet the growing and diversified demands of the market. Consequently, agriculture has not only continued to exist but also become so prosperous that a considerable financial surplus was accumulated which, in turn, was used to boost rural industrial 
development, leading to the formation of what some local Chinese scholars called "a double dualist structure" wherein agriculture and industry, urban and rural sectors, stand side by side. ${ }^{58}$

Unlike the experience of countries in South-East Asia where the persistence of agriculture as an economic sector for survival was a result of the fact that industrial expansion was unable to keep pace with population growth, the persistence and recent development of agriculture in Nanhai are primarily shaped by such factors as a well-established farming tradition, excellent natural endowment, and, most importantly, easy access to the large urban markets in Hong Kong, Guangzhou and Foshan which have kept market farming a profitable activity for the local people. In this regard, the experience of Nanhai has been significantly different from that of other parts of China, such as the lower Changjiang Delta, where market farming contributed little to the improvement of the peasant economy. ${ }^{59}$

While the commercialization of farming has contributed to higher household income and personal savings for peasants, rapid industrial development in the countryside is found to be the most powerful force directly responsible for much of the structural, spatial and environmental changes that have occurred. By creating a great number of factory jobs, rural industries have absorbed a substantial amount of surplus farm labour released by agricultural production. In this manner, rural industrialization has profoundly transformed the local economy from one of prolonged "involutionary growth" or "growth without development," into one of unprecedented genuine development. In a manner similar to that which has occurred elsewhere, rapid industrial development in the countryside of the delta has also enabled many local peasants to "enter the factory but not the city," thereby absorbing a massive rural exodus. ${ }^{60}$ Geographically, the flourishing of numerous small-scale industries in the countryside has facilitated rapid encroachment of industrial development over valuable farmland, leading to a mixture of intensive land uses between agricultural and industrial production or rural and urban activities. The primitive nature of such industrial development and its "hidden" location in the countryside have favoured an unfriendly or devastating treatment of the natural environment which has caused serious damage to the local ecosystem.

Recent phenomenal growth of production in both market farming and rural industry has been primarily a result of the state's relaxed control over the local economy of the Zhujiang Delta, not a consequence of any active government intervention. Statistical data from Nanhai clearly indicate that the state sector or publicly owned enterprises accounted for only 16 per cent of total capital investment, 13 per cent of industrial output value, 28 per cent of employment and 27 per cent of total tax revenue (Table 4). The private sector was not the chief economic player

58. Zhao Duanzhang, "Nanhai moshi," p. 185.

59. See Philip Huang, The Peasant Family and Rural Development, p. 17.

60. Ho, Rural China in Transition. 
Table 4: Sectoral Composition for the Local Economy of Nanhai, $1991(\%)$

\begin{tabular}{lccrc}
\hline Items & $\begin{array}{c}\text { State } \\
\text { sector }\end{array}$ & $\begin{array}{c}\text { Collective } \\
\text { sector }\end{array}$ & $\begin{array}{c}\text { Private } \\
\text { sector }\end{array}$ & Total \\
\hline Capital investment & 16.62 & 63.98 & 19.40 & 100.00 \\
Employment & 28.39 & 62.74 & 8.87 & 100.00 \\
Industrial output value & 14.22 & 71.42 & 14.36 & 100.00 \\
Tax revenue & 27.46 & 60.11 & 12.43 & 100.00 \\
\hline
\end{tabular}

Sources:

Row 1: Nanhai, Statistical Bureau, Nanhaixian 1991 nian tongji ziliao (Statistical Data for Nanhai County (1991)) (Nanhai: Internal document, 1992), p. 76. Row 2: ibid. p. 100. Row 3: ibid. pp. 6 and 54. Raw data are at the 1990 constant price. The private sector includes joint ventures whereas the collective sector includes all collectively owned enterprises in towns and villages as well as those in partnership. Row 4: Nanhai, Statistical Bureau, Nanhai 40 nian (1949-1988) (Nanhai's 40 Years (1949-1988)) (Nanhai: Internal document, 1989), p. 72. Data are for 1988.

either as its contributions to local financing, industrial production, employment and tax revenue were smaller than those of either the state sector or the collective units.

Ironically, it was after the de-collectivization of agricultural production that many co-operative organizations were formed spontaneously, based on mutual interests, to seek genuine economic development. This is especially evident in Nanhai where many collectively-owned or partnership enterprises have been set up to pursue large-scale and mechanized crop cultivation, to co-ordinate market farming and industrial development, and to run various township and village enterprises. The important role of these collective organizations in the local economy can be seen from the statistical data listed in Table 4. The collective sector contributed to the local economy 64 per cent of total investment, 63 per cent of employment, 71 per cent of industrial output value and 60 per cent of total tax revenue. This collective sector is, of course, not the same as the one established in the Mao years according to the principle of egalitarianism. Many "collectively owned" rural industrial enterprises are actually corporations managed by local cadres who act as the equivalent of the board of directors. In this regard, the experience of Nanhai has lent support to the thesis of "local corporatism." It should be noted, however, that while the central state is no longer actively and directly involved in local economic affairs, government policies that are made at

61. Jean Oi, "The role of the local state in China's transitional economy," The China Quarterly, No. 144 (1995), pp. 1132-49; Andrew Walder, "Local governments as industrial firms: an organizational analysis of China's transitional economy," American Journal of Sociology, Vol. 101, No. 2 (1995), pp. 263-301; Nan Lin, "Local market socialism: local corporatism in action in rural China," Theory and Society, No. 24 (1995), pp. 301-354. 
a macro-level, such as price adjustments and other regulations, continue to influence the fluctuation of agricultural production. ${ }^{62}$

Despite the growing complexity of rural development in the postreform Zhujiang Delta, it seems certain that overall the countryside of the region is experiencing a transitional process leading to the formation of a distinct type of peasant economy that is shaped increasingly more by market forces and motivated primarily by local community (village) initiative. Indeed, in this southern region where "the mountains are high and the emperor is far away" (shangao huangdi yuan), many particular features of economic and geographic transformation since the reforms have owed more to spontaneous developmental initiative from below than to the intervention of the state or active involvement of the central government from above.

62. Terry Sicular, "China's agricultural policy during the reform period," in Joint Economic Committee of the U.S. Congress, China's Economic Dilemma in the 1990s: The Problems of Reforms, Modernization, and Interdependence (Washington, D.C.: U.S. Government Printing Office, 1991), pp. 340-364; Terry Sicular, "Redefining state, plan and market: China's reforms in agricultural commerce," The China Quarterly, No. 144 (1995), pp. $1020-46$. 